Research Article

\title{
Review of justice for sustainability in the Covid-19 era
}

\author{
José Marcos Bustos Aguayo*, Margarita Juárez Nájera², Cruz García Lirios³, \\ María del Rosario Molina González ${ }^{4}$
}

\author{
'Department Psychology, Mexico University, Mexico City, Mexico \\ ${ }^{2}$ Department Energy, Metropolitan University, Mexico City, Mexico \\ ${ }^{3}$ Department Social Work, Mexico University, Huehuetoca, Mexico \\ ${ }^{4}$ Department Social Sciences, Sonora University, Navojoa, Mexico \\ ${ }^{*}$ Corresponding Author email: cgarciali@uaemex.mx
}

\begin{abstract}
The resources and services being public open the discussion about their redistributive justice. That is the differences between governors and governed orient community self-management or state management, discarding socio-state co-management as a balance between the parties. In this way, the objective of the study was to model the dimensions of justice for sustainability, considering a review from 2019 to 2021. A structure of five dimensions was found that explained the research discussion, suggesting the approach of tariff policies as regulators of environmental resources and sectoral demands. Thus, justice for sustainability is a central category in the conflict between public administration and users.
\end{abstract}

Keywords: Justice; Political Social; Welfare; Inequality; Public Resources

\section{INTRODUCTION}

Until September 2021, the pandemic has claimed the existence of more than four million humans and infected about 10 million (Organization for Economic Co-operation and Development, 2021, Abdullah et al., 2021). The World Health Organization (WHO) proclaimed it a global pandemic on 11 March 2020 (Abdullah et al., 2021; Ali et al., 2021). In this scenario of under-registration, justice is a central theme and axis of the biosafety agenda. On the one hand, the relevance of immunizing vulnerable sectors of the population is discussed, although on the other hand the interrelation between these sectors is encouraged. In this way, mitigation and containment policies, focused on confinement and social distancing, are evaluated from the justice system. Understood as a balance between the demands of the environment and internal resources, justice acquires a dimension of sustainability (Sandoval et al., 2021). It is about balance, social, political and economic between the availability of resources and consumption expectations.

The objective of this work was to establish the dimensions of justice for sustainability in the Covid-19 era, considering a review of the literature from 2019 to 2021. 
Are there significant differences between the theoretical structure reported in the literature with respect to the observations made in this study on justice to achieve sustainability as a balance between demands and resources in the face of the pandemic?

The premises that guide the study suggest significant differences between the theoretical structure with respect to the dimensions observed in the present work. This is so because justice for sustainability is a sub-discipline and area of knowledge built on the Millennium Goals (MDGs) and the Sustainable Development Goals (SDGs). In contrast, the criteria of experts on these issues are complemented by research findings that refute or verify the sustainable development agenda (Gonzalez et al., 2021). Consequently, asymmetries reflect generalities and specificities that define the sense of justice for sustainability.

\subsection{THEORY OF JUSTICE FOR SUSTAINABILITY}

The theoretical matrices that enliven justice for sustainability consider that it is a process that goes from the generality (Bustos-Aguayo et al.,2020).This is because the surrounding information in the investigative media generalizes the effects of the pandemic on sustainable justice, defining a public agenda. The investigative frames suggest that the pandemic is a determining moment of justice. In this vein, the impact of Covid-19 on justice for sustainability suggests a discussion of environmental demands and social resources. This asymmetry between the parties reflects a conflict between the actors. On the one hand, sustainability is a common and universal good. On the other hand, justice is a management instrument. While the pandemic involves differences between the parties involved. Sustainability is a common goal of balance (Garcia, 2021). Therefore, justice is only achieved if the pandemic is controlled, and sustainability is achieved.

In this way, from the theory of justice for sustainability, the SDGs are pandemic management instruments complementary to the mitigation and containment policies of Covid-19 Fleetwood, 2020). As governments manage to manage a balance of resources to face the onslaught of the pandemic, they promote sustainability in line with the scarcity of resources due to confinement and social distancing. In this sense, sustainability will achieve its status of justice until the parties resolve their conflicts. Rather, the pandemic itself entails policies of distancing and confinement that exacerbate differences between the parties (Pérez Ortega et al., 2021). While sectors access the resources to face the demands of a community transmission environment for the virus, others are excluded.

In this way, the theory of justice for sustainability predicts that conflicts are reduced when the parties involved establishing negotiations, agreements and joint responsibilities in the management of internal resources in the face of de-escalation of external demands (Garcia et al., 2020). From the balance of demands and resources, the theory of justice for sustainability recognizes the exclusion of sectors. These are groups whose management of the pandemic has been disrupted by the demand for resources.

Very soon, the management of sustainable cities was oriented towards the mitigation and containment of the pandemic as a complement to the reduction of the ecological footprint (Sandoval-Vázquez et al., 2021). In this sense, justice for sustainability emerged as an effect of the cities ascribed to the SDGs. The reduction of mobility and the attention to sectors that 
demand municipal services allowed to divert the discussion towards the promotion of green tourism. In this way, the pandemic was assumed to be transitory (Alvarado-Garibaldi et al., 2021). In the case of those displaced and migrants due to climate change, justice for sustainability understands that these are future events on which the SDGs regulate access to public services.

Even though laws and regulations are compatible with mitigation and containment policies around the discretionary management of resources in the face of the pandemic, justice for sustainability continues to have a community dimension (Ventura et al., 2020). While the State generates supply policies without considering the availability of resources, the community self-manages its expectations regarding these policies. This means a dialogue between public and social sectors and actors. In this negotiation and agreement, the co-responsibility indicated by the care of resources is reached.

\subsection{STUDIES OF JUSTICE FOR SUSTAINABILITY}

If the theory of justice for sustainability focuses its attention on the balance of demands and resources such as negotiations, agreements and co-responsibilities between the parties involved, the studies suggest differences between these actors and sectors (Juarez, Bustos \& Garcia, 2021). On the one hand, the differences arise since the SDGs divide the expectations of users of public services. Some support the optimization of resources and others warn of process innovation. It means then that sustainability can be an imposed unfair balance for sectors with expectations of self-management. On the other hand, the boom can fit into the SDGs, but public services reach a maximum of state goods (Hernandez et al., 2021). The ideal of self-management of common resources and services is different from the management of a pandemic from the SDGs.

The starting point for the investigation of sustainable justice lies in the conflict between the State and civil sectors (Hernández-Gracia et al., 2021). The differences due to the management of resources are constant, but the resolution is variable. The State must govern the SDGs without citizen participation. or self-management emerges as a response to ungovernability to move towards governance. Regarding the public administration, the balance is reached with the management of rates. Subsidies are a management and selfmanagement tool (Rincon, Carreon \& Garcia, 2021). While the State forgives the debts, the citizenship is organized around the regularization of the service with discounts to the municipal or community debt.

In fact, a balance between state management and civil self-management is comanagement (Garza et al., 2021). Both political and social actors organize themselves in situations of scarcity, unhealthiness and famine. Consequently, the municipal or public service reaches a status of co-responsibility. So, the issue of justice for sustainability turns towards its consistency in time and space (Vázquez et al., 2021). As the differences between public administration and users intensify, co-management underlies as an alternative to co-government through conflict and negotiation. In other words, governance inhibits justice and governance promotes it. 


\section{METHOD}

Design. Based on the theory of sustainable justice which suggests: 1) documenting the conflict between political and social actors regarding the availability of resources and human expectations of consumption; 2) analyzing the representation of costs and benefits between the public and private sectors; 3) propose lines of review concerning the differences already agreed between the parties involved.

Sample. A selection of indexed sources was made, considering the search by keywords: "Justice", "Sustainable", considering the publication period from 2019 to 2021 in international repositories: Academia, Copernicus, Dialnet, Ebsco, Frontiers, Latindex, Redalyc, Scielo, Scopus, WoS, Zenodo and Zotero (see Table 1).

Table 1. Description of the sample

\begin{tabular}{llll}
\hline \multirow{2}{*}{ Repository } & \multicolumn{3}{c}{ Justice } \\
\cline { 2 - 4 } & $\mathbf{2 0 1 9}$ & $\mathbf{2 0 2 0} \mathbf{2 0 2 1}$ \\
\hline Academy & 4 & 5 & 4 \\
Copernicus & 3 & 3 & 3 \\
Dialnet & 5 & 4 & 5 \\
Dimensions & 3 & 5 & 2 \\
Ebsco & 2 & 5 & 3 \\
Google & 4 & 5 & 4 \\
Frontiers & 3 & 4 & 5 \\
Latindex & 5 & 3 & 2 \\
Microsoft & 4 & 2 & 3 \\
Scopus & 4 & 4 & 4 \\
Zenodo & 4 & 5 & 5 \\
Zotero & 3 & 2 & 4 \\
Mendeley & 5 & 4 & 5 \\
JCR & 4 & 3 & 4 \\
\hline
\end{tabular}

Source: Elaborated with data study

The Delphi Inventory was used, which includes questions about the ratings of the dimensions of justice for sustainability. Upon being reported in the literature, the dimensions reached a logical structure: A unitary value for the community dimension by assuming that attachment processes and a sense of place and its resources prevail. A value of two was assigned for the norms, uses and customs of the locality. The number three to the reasons for balance between the external demands and the internal resources of the community. A value of four to the establishment of a local agenda and five to community participation (see Table 2)

Table 2. Dimensions of justice for sustainability

\begin{tabular}{|c|c|c|c|c|}
\hline Code & Repository & Author & References & Dimensions \\
\hline d1 & Academia & Bali Swain \& Yang-Wallentin (2020) & 49 & Participation \\
\hline$d 2$ & Copernicus & Ventura, Giulio, \& Rached (2020) & 40 & Agenda \\
\hline d3 & Dialnet & Bouman, Steg \& Dietz (2020) & 41 & Normative \\
\hline$d 4$ & Ebsco & Teymoori et al., (2020) & 30 & Rationality \\
\hline d5 & Latindex & Fleetwood (2020) & 12 & Community \\
\hline
\end{tabular}


Process. The Delphi technique was used to optimize the abstracts selected from a total of 37 sources in three rounds: 1) in the first qualifying phase, expert judges assigned a negative value to the abstracts that raised a justice without sustainability or sustainability without justice, as well as a positive value to the foundation of justice with sustainability or sustainability with justice; 2) in the second feedback phase, the averages were compared with each judge's rating; 3 ) in the third reconsideration phase the judges again scored the selected abstracts.

Analysis. Based on the theory of justice with sustainability, which warns of conflict, negotiation, agreements and co-responsibilities between the parties involved whenever meanings of resources and shared future are revealed, the qualifications of expert judges on the issues were interpreted (Garcia et al., 2021). In this way, the conflict was appreciated in the differences between the judges, the negotiation was observed in the comparison of averages with the first qualification, the agreements in the reconsideration of the qualification and the joint responsibility in the similarity of the final qualifications.

\section{RESULTS}

In relation to the conflict, the differences between the judges were appreciated in the first extract where a formative relationship between sustainability and justice is appreciated (see Table 3). When rating the summary, the experts disagreed with their criterion of considering justice with sustainability as opposed to justice without sustainability. Most assumed that sustainability is a narrative of green capitalism (resources are common and must be conserved for future generations) as opposed to the narrative of industrial capitalism (resources are exclusive for the comfort and recreation of developed generations).

Table 3. Description of instrument

\begin{tabular}{|c|c|c|c|c|c|c|}
\hline & $M$ & SD & KLS & C & & \\
\hline $\mathrm{R} 1$ & & & $N=160$ & $x 2$ & $d f$ & $\mathrm{p}$ \\
\hline d1 & 4.320 & 1.230 & 4.530 & 16.430 & 16 & $>.050$ \\
\hline$d 2$ & 4.560 & 1.430 & 4.670 & 17.650 & 17 & \\
\hline d3 & 4.760 & 1.560 & 4.520 & 14.350 & 15 & \\
\hline$d 4$ & 4.130 & 1.670 & 4.130 & 15.320 & 14 & $>.050$ \\
\hline d5 & 4.350 & 1.010 & 4.780 & 16.520 & 14 & \\
\hline $\mathrm{R} 2$ & & & $N=150$ & & & \\
\hline d1 & 4.030 & 1.430 & 4.310 & 15.320 & 16 & \\
\hline$d 2$ & 4.520 & 1.530 & 4.570 & 14.350 & 15 & \\
\hline d3 & 4.210 & 1.250 & 4.760 & 13.240 & 17 & $>.050$ \\
\hline$d 4$ & 4.370 & 1.670 & 4.320 & 15.460 & 18 & \\
\hline d5 & 4.890 & 1.760 & 4.130 & 16.570 & 15 & $>.050$ \\
\hline R3 & & & $N=140$ & & & \\
\hline d1 & 4.320 & 1.530 & 4.360 & 14.310 & 14 & \\
\hline$d 2$ & 4.560 & 1.570 & 4.310 & 15.460 & 13 & $>.050$ \\
\hline d3 & 4.680 & 1.430 & 4.530 & 16.570 & 15 & \\
\hline$d 4$ & 4.360 & 1.230 & 4.670 & 13.240 & 16 & $>.050$ \\
\hline$d 5$ & 4.330 & 1.530 & 4.870 & 14.320 & 14 & \\
\hline
\end{tabular}

Source: Elaborated with data study.

$d 7=$ Participation,

$d 4=$ Rationality,

$d 2=$ Agenda,

d3 = Normative, $d 5=$ Community 
Regarding the negotiation, the judges mostly accepted the comparison of their qualifications, establishing the possibility that green capitalism may be an extension of industrial capitalism (see Table 4). This is yes because the conservation of resources, according to the negotiation between the judges, is not enough to achieve sustainability. They only agreed to assume that public or private resources do not guide a policy, strategy or program towards sustainability because they would be managed from a logic of scarcity or abundance, inhibiting their long-term conservation. Extract two that proposes associating the public agenda with justice exemplifies this phase of negotiation since the judges widely deliberated the relevance of including natural resources as an axis and central theme as public services with a rating system to guarantee subsidies.

Table 4. Relations between dimensions

\begin{tabular}{|c|c|c|c|c|c|c|c|c|c|c|c|c|c|}
\hline & $M$ & SD & 0 & d1 & d2 & d3 & d4 & d5 & d1 & d2 & d3 & d4 & d5 \\
\hline d1 & 21.340 & 13.240 & .6210 & 1.000 & & & & & 1.546 & .543 & .436 & .546 & .367 \\
\hline$d 2$ & 24.310 & 15.430 & .6540 & $.432 *$ & 1.000 & & & & & 1.678 & .432 & .546 & .548 \\
\hline d3 & 25.460 & 13.560 & .6530 & $.356^{*}$ & $.357^{*}$ & 1.000 & & & & & 1.843 & .436 & .543 \\
\hline$d 4$ & 23.150 & 13.240 & .6500 & $.312 *$ & $.456^{* *}$ & $.546^{* * *}$ & 1.000 & & & & & 1.932 & .547 \\
\hline d5 & 27.650 & 12.150 & .6750 & $.436^{* *}$ & $.436^{*}$ & $.427^{*}$ & $.43^{*} 6$ & 1.000 & & & & & 1.547 \\
\hline \multicolumn{14}{|c|}{$\begin{array}{ccc}\text { Source: } \text { Elaborated with data study. } & \begin{array}{c}\text { M }=\text { Mean, } \\
\text { Omega excluded value dimensions, }\end{array} \quad d 7=\text { Participation, } & d 2=\text { Agenda, } \quad d 3=\text { Normative, }\end{array}$} \\
\hline
\end{tabular}

In relation to the agreements, the judges agreed in assuming that the resources must be common to represent and project sustainability with justice and equity (see Fig. 1). In this sense, extract five was illustrative of the agreements between the parties, although equity obeys a type of social justice related to sustainability in terms of access to resources. Excerpts one and three reflect the agreements between the experts when they agree that justice is formative of sustainability.

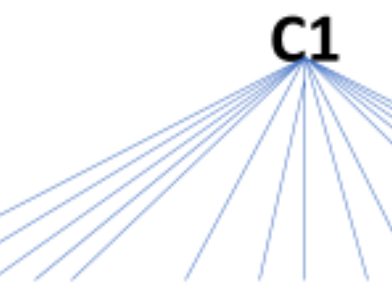

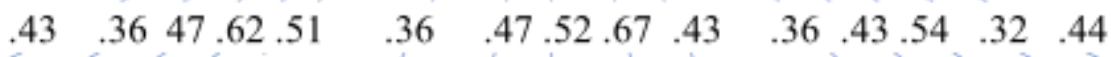

R1d1 d2 d3 d4 d5 R2d1 d2 d3 d d d5 R3d1 d2 d 3 d4 d5

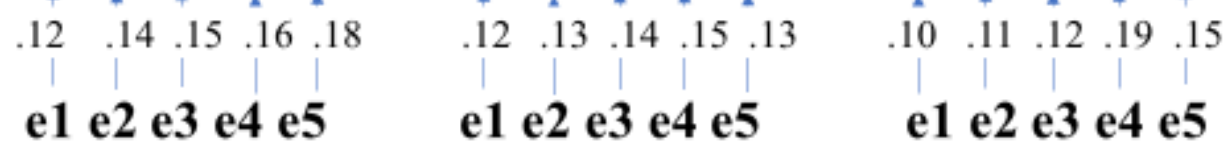

Fig. 1. Structural equation modelling

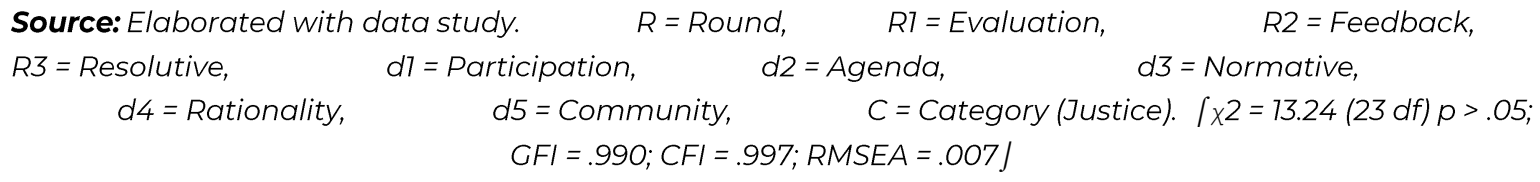


Regarding co-responsibility, most of the judges reached this level of consensus by ratifying their position regarding justice with sustainability rather than sustainability with justice. The first signifies a degree of social discussion around the public agenda, its axes and themes. The second option is a strategy for economic growth and production that is bound to fulfill a social responsibility to captivate its consumers. Extract four reveals commitment as the factor that will allow achieving social justice with equity and sustainability.

\section{DISCUSSION}

The contribution of this work to the state of the question lies in the theoretical and conceptual modeling of justice with sustainability from a systematic review of the literature and its processing using the Delphi technique where experts went through the four stages of the theory: conflict, negotiation, agreements and co-responsibility.

However, Garza et al. (2021) assure that justice with sustainability is the result of the appropriation of spaces and resources rather than the conclusion of agreements between the governors and the governed. In this work, we advance towards a discursive model in which the parties involved achieve goals based on shared objectives. Review and analysis lines concerning spaces and resources will allow us to notice public administration scenarios based on negotiation between political and social actors.

The contribution of this work to the state of the art is the modeling of the dimensions of justice for sustainability. Indicated by five dimensions related to participation, agenda, regulations, rationality and community. These are axes and topics of investigative discussion reported from 2019 to 2021 in a selection of indexed sources. Lines of study concerning the contrast of the model in other scenarios and samples will allow building public policies. Public resources and services that inhibit or promote sustainability by including biosafety protocols are approaching a phase of justice. In this sense, the balance between the demands of the environment and internal resources will allow progress towards the implementation of tariff policies that guarantee their optimization (García, 2020). Future generations will be able to access public services as long as they include the participation of sectors, a public agenda, the regulations of the SDGs, environmental rationality and a sense of community.

\section{CONCLUSION}

The objective of the study was to capture the dimensions of justice for sustainability. Based on a review of the latest studies, five explanatory dimensions of the balance between available resources and the demands of the environment were examined. The results show that experts in the topics differentiated five dimensions reported in the literature and established an explanatory structure. It is a sequence of dimensions that reflect a justice for sustainability in the making because it only points towards the incidence in public policies. The transformation of the industrialized welfare state into an informational one will be possible to observe at the level of equilibrium between the parts. This is so because the surrounding data in the media and networks can describe the asymmetries between the rulers and the ruled, but in a scarcity scenario they cannot anticipate joint responses. In this 
way, the demands of the environment are managed from the logic of scarcity, unhealthy and low-cost resources, as well as their diffusion.

\section{Reference:}

Abdullah, I., Parveen, S., \& Haq, S. U. (2021). Forced online experiment and its acceptance among the University students during pandemic in Pakistan. foresight. https://doi.org/10.1108/FS-012021-0026

Abdullah, I., Parveen, S., Shahid K. N., \& Abdullah, D. (2021). Anxiety, OCD, delusions, and religiosity among the general public during the COVID-19 pandemic. International Social Science Journal, 71(241-242), 163-178. https://doi.org/10.1111/issj.12284

Ali, Q., Parveen, S., Yaacob, H., Zaini, Z., \& Sarbini, N. A. (2021). COVID-19 and dynamics of environmental awareness, sustainable consumption and social responsibility in Malaysia. Environmental Science and Pollution Research, 28, 56199-56218. http://dx.doi.org/10.1007/s11356-021-14612-z

Alvarado-Garibaldi, S., Carreón-Guillén, J., \& García-Lirios, C. (2021). Modeling of the mobility habitus in the public transport system with low $\mathrm{CO} 2$ emission mechanics in the center of Mexico. Advances in Mechanics, 9(2), 82-95.

Bali Swain, R., \& Yang-Wallentin, F. (2020). Achieving sustainable development goals: predicaments and strategies. International Journal of Sustainable Development \& World Ecology, 27(2), 96-106. https://doi.org/10.1080/13504509.2019.1692316

Bouman, T., Steg, L., \& Dietz, T. (2021). Insights from early COVID-19 responses about promoting sustainable action. Nature Sustainability, 4(3), 194-200.https://doi.org/10.1038/s41893-02000626-x

Bustos-Aguayo, J. M., Aldana, W. I., Hernández, T. J., \& García, C. (2020). A review of findings about local development. Eureka, 17(1), 141-161. https://psicoeureka.com.py/publicacion/17-1/articulo/16

Fleetwood, J. (2020). Social justice, food loss, and the sustainable development goals in the era of COVID-19. Sustainability, 12(12), 1-9. https://doi.org/10.3390/su12125027

Garcia L. C. (2021). Escenarios Hídricos en la Ciudad de México: Revisión de 2019 a 2021. Revista de Geografía Espacios, 11(21), 48-63. https://doi.org/10.25074/07197209.21.1895

Garcia, C., Bustos, J. M., Juarez, M. \& Sandoval, F. R. (2021). Contrastación de un modelo de gobernanza de la sustentabilidad hídrica. Revista de Estudiantes de Ciencia Política, 15(1), 143-162. https://revistas.udea.edu.co/index.php/recp/article/view/346930/20805805

Garcia, C., Juárez, M., Bustos, J. M., Sandoval, F. \& Quiroz, C. Y. (2020). Specification a model for study of perception risk. Education \& Technology Environment, 24(43), 1-8. https://doi.org/10.5902/2236117045266

García, C: (2020). Specification a model for study of interventions. Global Journal of Human Social Science, 20(1), https://socialscienceresearch.org/index.php/GJHSS/article/view/3089/2978

Garza-Sánchez, J. A., Hernández-Gracia, T. J., Campos-Guido, L. L., Coronado-Rincón, O., HernándezValdés, J., Bermúdez-Ruiz, G., \& García-Lirios, C. (2021). SPECIFICATION OF A MODEL OF SUSTAINABLE JUSTICE. PalArch's Journal of Archaeology of Egypt/Egyptology, 17(4), 28272845.

Gonzalez, L. M., Sanchez, A., Carreon, J., Espinoza, F. \& Hernandez, J. (2021). Discursive Collaborative Networksina Coffee-Growing Town. Turkish Online Journal of Qualitative Inquiry, 12(6), 4765-4771. https://www.tojqi.net/index.php/journal/article/view/2179/1305

Hernandez, T. J., Carreon, J. \& Garcia, C. (2021). Factor structure of the determinants of entrepreneurship in the era of biosafety in the face of Covid-19. Academy of Strategic Management Journal, 20(2), 1-8. 
Hernández-Gracia, T. J., Guillén, J. C., \& García-Lirios, C. (2021). Reengineering in The Entrepreneurship of the Coffee Industry and Tourism in Central Mexico. Advances in Mechanics, 9(2), 63-81. Retrieved from http://advancesinmech.com/index.php/am/article/view/36

Juarez-Najera, M., Bustos-Aguayo, J. M., \& García-Lirios, C. (2021). Structural factors of expectations regarding the public drinking water service in a town in central Mexico. Public Security \& Public Order, 27(1), 51-59. Retrieved from https://repository.mruni.eu/bitstream/handle/007/17582/6553-15791-1PB.pdf? sequence=1\&isAllowed=y

Organization for Economic Co-operation and Development (2021). Statistics by selected countries. New York: OECD. https://stats.oecd.org/

Pérez Ortega, M., Bustos Aguayo, J., Juárez Nájera, M., \& García Lirios, C. (2021). Actitud hacia los efectos de Covid-19 en el medio ambiente. Revista De PsicologíA De La Universidad AutóNoma Del Estado De MéXico, 10(20), 9-29. doi:10.36677/rpsicologia.v10i20.16708

Rincon, R. M., Carreon, J. \& Garcia, C. (2021). Contrast of a model of quality of life in the center Mexico. Academy of Social Science Journal, 6(6), 2100-2112

Sandoval, F. J., Bustos, J. M., Juárez, M. \& García, C. (2021a). Specification a model for study of social $\begin{array}{llll}\text { work sustainability. } \quad \text { Amazonia, } & \text { 343-353. }\end{array}$ https://periodicos.ufam.edu.br/index.php/educamazonia/article/view/8422/6001

Sandoval-Vázquez, F. R., Juárez-Nájera, M., Bustos-Aguayo, J. M. \& García-Lirios, C. (2021). Modeling the environmental perception published in the literature from 2019 to 2021. Turkish Journal of Computer and Mathematics Education (TURCOMAT), 12(13), 5507-5517.

Teymoori, A., Perkins, T. J., Pâslaru, V., Cohnitz, D., \& Trappes, R. (2020). The Online Alternative. Sustainability, Justice, and Conferencing in Philosophy. European journal of analytic philosophy, 16(2), 145-171. https://doi.org/10.31820/ejap.16.2.7

Vázquez, F. R. S., Ruíz, H. D. M., \& Lirios, C. G. (2021). Meta-Analytic Network Retrospective of Public Transport and its Effects on the Governance of Health. International Journal of Advances in Social Sciences, 9(1), 08-18. https://doi.org/10.5958/2454-2679.2021.00002.5

Ventura, D. D. F. L., Giulio, G. M. D., \& Rached, D. H. (2020). Lessons from the Covid-19 pandemic: sustainability is an indispensable condition of Global Health Security. Ambiente \& Sociedade, 23. https://doi.org/10.1590/1809-4422asoc20200108vu2020 L3ID 